\title{
Improving Students' Speaking Performance through Video
}

\author{
Dwi Prihati ${ }^{1}$, Ashadi $^{2}$ \\ \{dwie.thedreamer@gmail.com\} \\ ${ }^{1,2}$ Yogyakarta State University, Daerah Istimewa Yogyakarta, Indonesia
}

\begin{abstract}
Speaking ability is often considered as the mastery indicator in language learning. On the other hand, teaching speaking is not an easy thing due to the complexity of the speaking itself. This article examined the lack of vocabularies and poor pronunciation, together with low motivation, less confidence, and students' boredom, as the problems commonly faced by the nonEnglish department students in a private University. Intending to improve their speaking performance, the study employed classroom action research in a speaking class held in the language center of the university. This action research used video as the main media, to be the main action given and some accompanying actions like listen and repeat, group work practice, and game. After two cycles of action, it was found that there was an improvement in the students' speaking performance in form of the increase of vocabulary and the reduce of tendency to read text.
\end{abstract}

Keywords: speaking performance, video, non-English university students.

\section{INTRODUCTION}

Language is a means of communication through which people interact with one another to exchange opinions and information. The communication happens in oral or written form. Oral communication takes place through speaking, while written communication happens through writing. Both speaking and writing are productive skill in language learning. The other two, reading and listening, are the receptive skill of language learning. All the four aspects are important that none of them is more important than the others. Speaking, however, is somehow considered as the measurement of the language mastery [1]. In terms of communication, especially daily communication, people mostly use spoken rather than written form. For that reason, speaking is inevitable for people. It is also because of the nature of speaking that becomes a crucial part of human life. Speaking involves more than a person, as stated by Harmer [2], speaking involves interaction of a person with one or more participant.

Speaking happens for many reasons and purposes. Lindsay and Knight, in [3], mentioned that people speak for many reasons- to socialize, ask for something, want other people to do something, to do something for someone else, to give response, to state feelings, opinions or emotions, to exchange information, to refer to an action or event in the past, present, or future, the possibility of something happening, and so on. In shorter words, speaking happens for intrapersonal and transactional purposes $[4,5]$. Intrapersonal is used to keep social interaction, and transactional is used as a proportion or to get information or something done [5]. In addition, speaking is the second skill that people usually used after listening and then followed by reading and writing $(45 \%, 30 \%, 16 \%, 9 \%$ respectively) [6].

Moreover, speaking requires real time or direct response, making it harder than the other skills of language. People do not have time to prepare the response when they are engaging in 
a conversation. People need to have enough language repertoires to be able to involve in a fluent conversation with other person or community. It is, of course, a little bit difficult than the other skills, writing for instance that still enables the language users to prepare and consult dictionary if needed.

The important aspect of speaking in one's daily life is the position of English in international world. Since English becomes the international language spoken all over the world $[7,8]$, people use it to communicate in daily conversation, particularly when meeting people from different country. The status of English as the international language also results in the need of people to master English actively by being able to speak it.

Referring to the importance of speaking, the teaching of speaking in language learning, thus becomes very important. On the other hand, EFL students find it difficult to speak. Many research reported that the speaking skills of EFL students is still far from satisfactory $[9,10]$. Research also reported that students in Indonesia have low performance of speaking due to some reasons such as unwillingness to speak [11], low confidence [12, 13], and poor linguistic mastery (i.e. pronunciation, grammar, vocabulary, fluency) [14]. Therefore, teachers need more effort to improve the students' speaking skill. This study tries to do so.

\subsection{Teaching Speaking}

Speaking is crucial in learning a second language. It is said the success of learning English is the students' speaking skill. The students tend to measure their improvement by practicing to speak in English [15]. In line with Richards[15], Cole et al. [16], states that speaking is very important in mastering a second language and it's also used in daily life. As mentioned in the introduction, is the essence in learning a second language. In teaching speaking, teachers have to consider some issues like conversational discourse, teaching pronunciation, accuracy and fluency, affective factors, and the interaction effect to help them in choosing methods and techniques. In fact, students face some problems in speaking because of the characteristics of spoken language like clustering, redundancy, reduced forms, performance variables, colloquial language, rate of delivery, stress, rhythm, intonation, and interaction [5].

Generally, in teaching speaking, many teachers only teach students on how to use the language to communicate, without paying attention to the other aspects, such as pronunciation, fluency, accuracy, and choices of proper words for proper expressions. If the focus is only on the teaching students to communicate bravely and building their confidence, their pronunciation, their ability to choose the appropriate word for appropriate expression, their fluency and their accuracy will be weak. Therefore, the teachers have to pay a lot of attention to enrich students speaking ability.

On the other hand, teachers are challenged in teaching speaking because teaching speaking is not an easy thing. Many students in EFL classroom are difficult to speak English and "don't want to speak English" [12]. There are many problems related to the teaching speaking in the classroom as mentioned in the background before. The problems faced by the students and teachers are different for each class. For example, students might have low level achievement of speaking as they are afraid of making mistake, have lack of vocabularies and lack of confidence, etc. Based on the writers' observation and experience in teaching speaking classes, it is found that the students at the Basic English Speaking Course in a private university in Central Java have difficulty in fluently speaking the target language. The students tend to write what to say and read what they have written. Based on the preliminary observation and informal interview with some students, the main problem making the students in that situation is their lack of vocabularies. This main problem comes along with the other 
problems such as less confidence and low motivation in learning English. They join the class only because they have to. Some of the students also admit that they have no interest in learning English because they think that English is difficult and English does not have direct relationship with their major. Some others think that the class was so boring. The low motivation of learning causes their ignorance during the teaching and learning process.

Considering the afore-mentioned problems faced by the students in their speaking class, the writers focus only on lack of vocabulary and speaking fluency problem as the targeted problems. The writers, then propose a teaching technique that employees the video as the main media in the classroom. As the students are mostly millennial students getting a high exposure of technology, video is expected to attract their intention to learn English, and therefore it can change the classroom atmosphere into the better one and increase the students' speaking performance.

The choice of video is based on some consideration. First, video is an effective media to improve students' speaking skill as what stated by Angkananon \& Wald[17]. They conducted experimental research in Thailand. The result was that students who are given treatment got higher score than those who didn't get any treatments. Another study has been done in Turkey [18], the finding is that using video in teaching speaking can improve students' speaking skills. Second reason of the use of video as the main action is because of the result of the questionnaire on students' learning style. The result of questionnaire adopted from Chislett and Chapman[19] showed that most students are visual student which is also in line with the statement from Cohen[20]who argued that most university students are visual and auditory learners.

The video used are video from YouTube based on its benefits. Dieu, Campbell, \& Ammann, as cited in Brook [21], argue that YouTube can provide authentic context for communication and interaction, and also enable the students to negotiate for meaning, to develop fluency, and to learn from others, and trigger students' creativity as well.

\section{METHOD}

This study was a classroom action research (CAR) which employed Kemmis and McTaggart's (as cited in [22]) phase model. The phases of the action research were: planning, action, observation, and reflection. Planning phase were about problem identification and determination of which problems are feasible to resolve and also the choosing of the action to make improvement of the targeted problem. In this phase, the writers deliberately determined the action taken, which is video as the main action. Making lesson plan, materials, and media were also done in this phase. The second phase was action, which is the implementation of the proposed solution for the targeted problem. In this phase, the writers implemented the use of video as the main action together with listen and repeat, game, and group work in the speaking class. The next phase was observation, in which the writers documented and recorded everything happened during the implementation of the action. One member of the researchers taught the students using the video and the other member made classroom observation checklist and documented the process of teaching and learning process by using smartphone camera. The last phase was reflection. In this phase, the researchers evaluated the implementation of the action and made conclusion whether the action was successful or not.

The research was conducted in a private university in Magelang. The subjects, 30 people, were students from a study program, non-English Department, in the university having the speaking class held by the language center. The speaking class was a zerocredit subject but 
compulsory for the students. The research was done from March to April 2019. It consisted of two cycles with two meetings for each cycle.

To get the data, the researchers employed observation, which was made into vignette later on, and speaking test. Observation checklist and speaking scoring rubric were the instruments to collect the data. The scoring rubric used was the existing scoring rubric occupied by the language center in speaking test.

The data of this research were in form of qualitative (the process) and quantitative (the outcomes). Hence, the data analysis of this research was mixed method of qualitative and quantitative. The qualitative data were analyzed by using the five steps suggested by Burns [22] consisting of assembling the data, coding the data, comparing the data, building meanings and interpretations, and reporting the outcomes. In assembling the data, the researchers compile all data from the implementation of the action. After that, the data were then identified and then grouped into similar pattern. The next step was comparing the patterned data with the data from the observation and their speaking test result. Building meaning and interpretation was the most difficult part of the analysis. In this step the researchers thought deeply about what comes and what is indicated from the data. This was then continued by presenting the outcomes of the research.

The quantitative data from the research, in form of the speaking test result, was analyzed using descriptive analysis. The simple calculation by using Microsoft excel was used to obtain the mean of the students' speaking result. It was used to know whether or not there was improvement before and after the action.

\section{RESULT AND DISCUSSION}

This section provides the explanation of the implementation of the cycles and the result of the implementation of the action. The result of the data analysis is presented following the steps mentioned in the previous section. It is presented for each cycle of the action. At the end of each cycle, reflection is conducted to make conclusion of the action, whether or not it obtains the expected condition.

\section{a. Findings of Cycle I}

Cycle I was conducted in two meetings. The whole cycles were started by identifying the problems in the classroom and determining the targeted problems which have been mentioned in the background of this study. The writers suggested video to overcome the problem aroused in the teaching and learning process. After all preparation for cycle I, consisting of the making of lesson plan, materials, media, and rubric, was done, the writers were about being ready to start the action. Before starting to implement the action, however, the writers did a test to know the students' initial speaking performance. Though the target of the action is not the final achievement, but rather the process and the performance, it is still important to conduct the test before action implementation in order to know the profile of the students speaking skill before the action. From this test, it was known that most students feel worried when they had to speak. Almost all students described their friends only in words, not in a complete English sentence. Some of the students also use Bahasa Indonesia when describing the person. The excerpt taken from the vignette below showed the situation of the class.

...Most students did not use complete sentence to describe their friend. They say only the words such beautiful, handsome, fat, tall, smart, and so on. Some of them were 
looked so worried and said "Bu, kalau tidak tahu Bahasa Inggrisnya bagaimana, boleh pakai Bahasa Indonesia?".... (Vignette 1)

The implementation of cycle I was then started after the initial test. The topic in cycle I was describing people. Two members of the researchers did the observation checklist while one of them was delivering the materials. The writers wished to play the video on describing people first, but due to the technical trouble with the video, PowerPoint presentation was firstly showed. The presentation was about parts of human body in general and aspects to describe from someone such as face (round, oval, etc.), nose (pointed, big, button, etc.), eyes (small, big, slanted, etc.), personalities (diligent, kind, friendly, etc.). The next step was video playing, but it was only in form of audio first. While listening to video, the students were asked to write down vocabularies while they were listening to the audio and continued by mentioning what they have written. This action was aimed to give positive impact on the students' vocabularies. Then, the students were encouraged to check their wording by playing the video containing the subtitle.

In the second meeting of cycle I, the writers played the same video at a glance to check their understanding and memory. Group work (practice) was the main activity in the second meeting. The students were asked to form groups and play guessing game within their group. This kind of activity was chosen to make them feel more secure and relaxed when speaking. A student had to describe a person and the rest group members should guess the person being described.

During these activities, the researchers were in the groups to record the students' speaking performance. In this activity, it was found that the students had a great progress in term of their fluency and vocabulary. The students did not use Bahasa Indonesia anymore in speaking. The students were able to make good grammatically correct sentences and they did not need long pause to think of sentence to describe. The most important progress was they became more confident to speak spontaneously without reading text as what they used to do. Considering the result if cycle II, it can be concluded that the actions to improve students' speaking performance in this cycle was successful. It was described in the following excerpt of vignette.

...It was a fun activity for them proven by so many laugh and joke when they guessed the person being described. They also did not feel afraid of making mistake anymore. The most important thing was that they tried to speak without reading the text as what the students used to do. Some students still read the text, however, but not so often. The frequency of reading text was lowered.... (Vignette 2)

From the result of the speaking test, it was found that there was improvement in students' fluency, vocabulary and overall score. The increase of vocabulary was noticed from the reduce of the use of Bahasa Indonesia when speaking while the improvement of fluency was noticed from the increase of spontaneity of speaking and the reduce in filler words and pauses of speaking. Chart below shows the students' progress before (test 1) and after the action (test 2). 


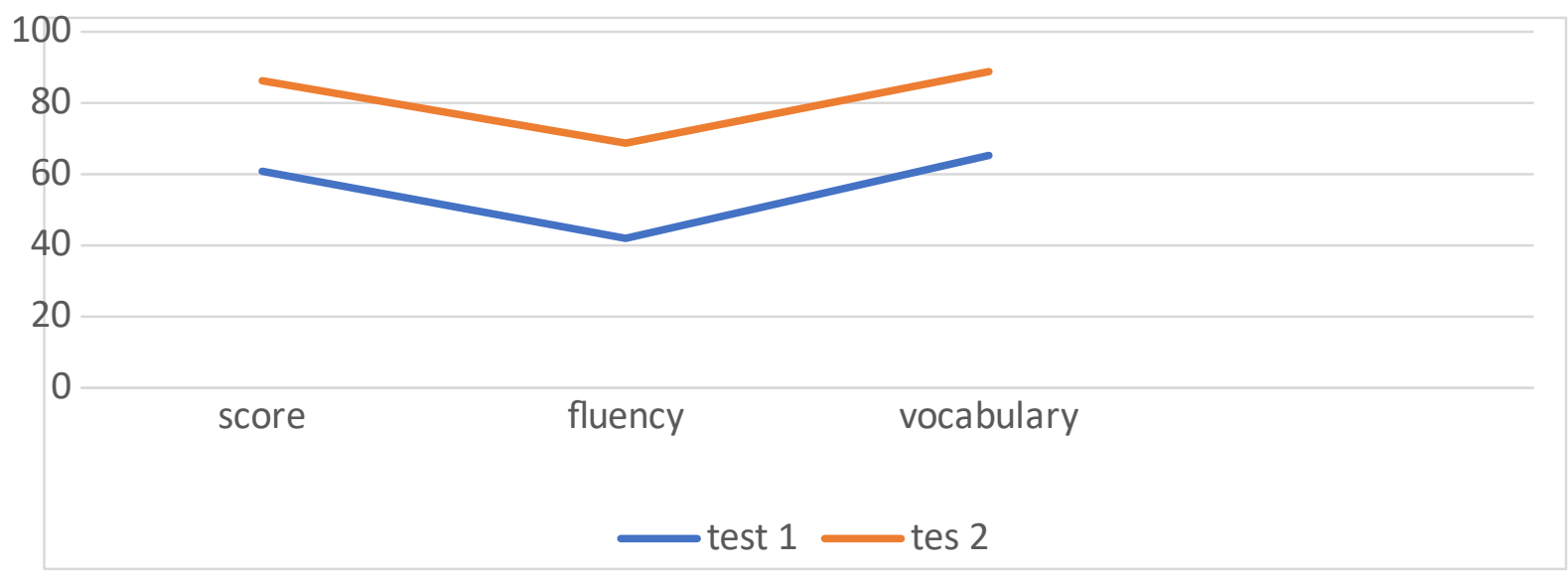

Figure1. Students' progress in cycle I

However, there was notion that some students still occasionally looked at their notes due to their fear of making mistake when speaking without any text. Therefore, cycle II was designed to overcome this problem.

\section{b. Findings of cycle II}

The action was continued to cycle II. Cycle II also consisted of two meetings. The topic in this cycle was daily activities. The main action was still video watching. Listen and repeat and group work were also the accompanying action in this cycle. In group work, however, the groups were smaller than the cycle I. It was aimed to make the students fell more relaxed and confident as they practice within very small group. Therefore, it can reduce the students' dependency to read the text as a result of their unconfident feeling.

In meeting I, the students were triggered to think and answer some questions related to daily activities as the warming up activities, and surprisingly, they spoke English to answer the questions and did not seem feeling afraid to talk anymore. The activity in meeting 1 cycle II started by the discussion about the type of tense used to tell daily activity, its pattern, and function. The main activity in this meeting was video watching. The video was about vocabularies related to daily activities. Similar to the action in cycle I, the video was firstly made as audio only. While they were listening to audio, they had to write down the vocabulary they listen and then mentioned the vocabularies they found and check their pronunciation and the unknown meaning of the words. This activity was able to improve their vocabulary as the basic need of speaking. The main activity was continued by playing the video with the subtitle. The students checked the wording and spelling of the vocabularies.

In the second meeting of cycle II, language aspects related to daily activities, such as adverb of frequency, preposition of time, conjunction/connectors, were discussed. Video playing was still the main activity in this meeting. The video in this meeting, however, was different with the video in meeting 1 . The video contained the conversation related to someone's daily activities. The accompanying action was group work but in a smaller group than the cycle I. within their group they had to tell their daily activities. To make it different with usual activity in the classroom, where a student speaking and the others listen to him/her, 
the practice of speaking were made in group and they had to make a kind of conversation in telling their daily activities. Using this way, the classroom atmosphere of the speaking activity was more vivid. The students did not feel bored waiting their turn to speak as the previous classroom setting. The students enthusiastically spoke to their friends within their group. In this activity, the writers took notes of the students' speaking performance using the available rubric.

From this activity, it was found that the students still show a progress on their speaking performance. The notion of cycle I in which some students still occasionally read notes were minimized very well. Only very few students still did that. It might be because of their unconfident character that they feel safer to look at notes. These students did not read their notes all the times but only occasionally. From the reflection of this cycle, it came to the conclusion that there was an improvement in the students' speaking performance. The chart below described the students' improvement in cycle I and cycle II.

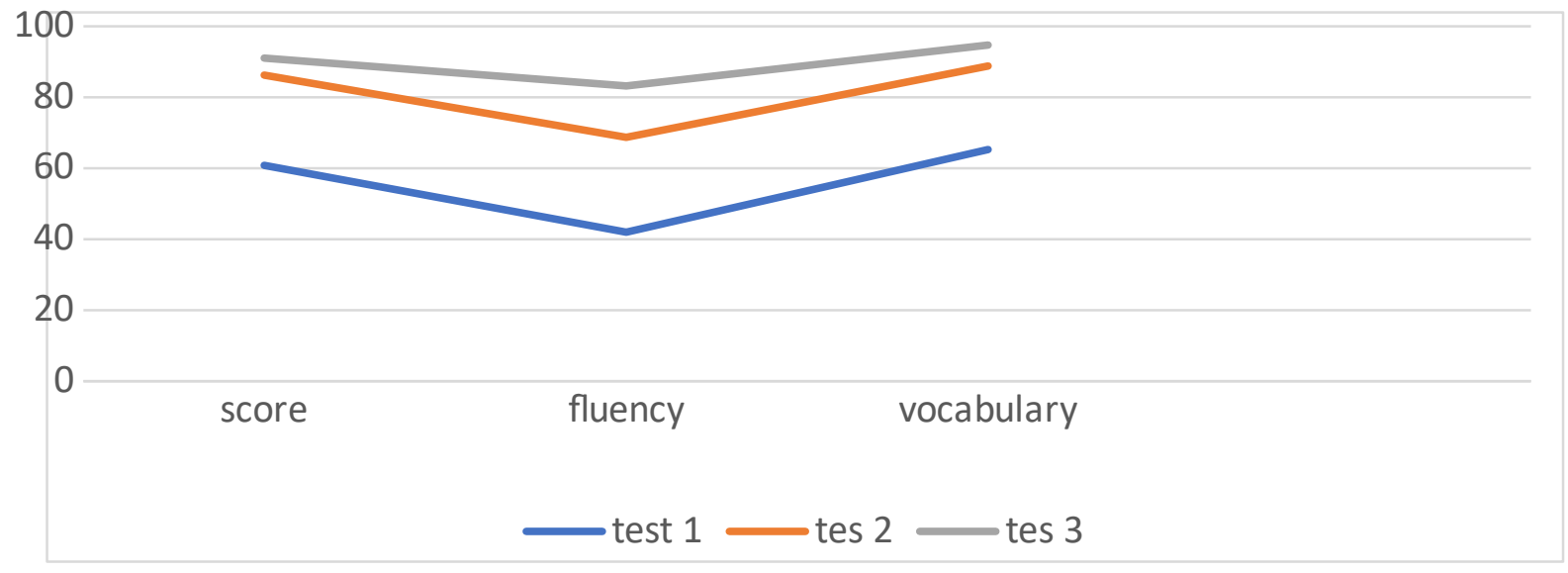

Figure 2. The improvement of the students' performance after the two cycles

\section{DISCUSSION}

This part presents the discussion of the research results by comparing to theories and other similar research. To begin with, as the basis belief of this research goes, the result of this research is in line with the statement from Cohen [20] mentioning that most university are visual and auditory learners, and therefore, the best media to teach university students are visual-based and auditory-based media to help them achieve the best performance. Video chosen as the main action is this research can be both visual and auditory-based media and it is proven from the result of the research that the video is able to facilitate the students in improving their speaking performance.

Another basis belief of this research is the principles in teaching speaking stated by Brown [5]. He mentions seven principles of teaching speaking consisting of the emphasis on the importance of spectrum on learners' needs from accuracy, meaning-form, meaning and fluency, providing motivating technique, encouraging the use of authentic language, providing positive feedback and correction, employing the natural link between speaking and listening, giving the change to initiate speaking, encouraging the development of speaking strategies. For example, encouraging the use of authentic language, and employing the natural link 
between speaking and listening. The video used in this action is in full English and involves native speakers the as the voice over. Watching video means listening to what the speakers say as they are inseparable. Thus, this fact really matches the principle of employing natural link between speaking and listening.

Furthermore, this result is in line with a research conducted by Mustikawati [23]. She conducted a research in Prambanan by using experimental research, and the result was that students who are given treatment got higher score than those who didn't get any treatments. Video is an effective media to improve students' speaking skill based on the result of this study, similar to this research result showing an improvement in students' score, students' participation, and their engagement. This indicates the similar finding resulting from two different kinds of research. There are similar research resulting in the same finding such as some mentioned in the background[17, 18, 24]

From all of those considerations, teaching speaking by using video is recommended for EFL teachers, particularly in university context, in improving students' speaking skill. It is in accordance with the learning style of most university students, interesting for students and providing authentic and meaningful materials.

\section{CONCLUSION}

As mentioned in the introduction, this research is conducted due to gap found that teaching speaking is difficult but often considered as the language mastery indicator. Likewise, the success of the teaching speaking is often considered as the success of teaching a foreign language. Nonetheless, many students' find it difficult in speaking class due to some problems. The problems highlighted here, as mentioned in the introduction, are the lack of vocabulary and speaking fluency. Teaching speaking using video is the action given to solve the problems.

The results show that the use of video is able to improve the students' speaking performance. The increase of the vocabularies can be seen from the teaching and learning process, where the students can speak complete English sentences and minimize the use of Bahasa Indonesia after the action. In term of the improvement of speaking fluency, the students show less dependence to their written text as what they used to be. They are now become more confident in speaking English, and even they speak without any notes, and also normal pauses. A very few students however, still occasionally try to look at their notes while speaking. This situation might be because of the students' hesitance and anxiety of making mistake. Further research should address this problem. The general success can be seen from the statistical data showing the great improvement of the mean score between the initial speaking test and after the action was conducted. Overall, the classroom situation tends to be the real speaking class, not reading class where the students read their written concept.

Regardless the success of this action, however, this research is far from perfect. The result of this research, of course, cannot be generalized as the nature of an action research itself. The success of the use of video in improving the students' speaking in this context might have different result in different institution, classes, and context, and therefore the similar action need to be conducted in either similar or different situation. At last, the numbers of meetings need to be more than 2 meetings for each to result in more tangible data. 


\section{REFERENCES}

[1] S. Nazara, "Students' Perception on EFL Speaking Skill Development," JET (Journal English Teaching), vol. 1, no. 1, p. 28, 2011

[2] J. Harmer, The Practice of English Teaching. London: Pearson Education Limited, 2001.

[3] C. De Junio, "the Importance of Teaching Listening and Speaking Skills," World Sci., 2018.

[4] D. Nunan, Second language teaching and learning. Boston: Heinle and Heinle Publishers, 1999.

[5] H. D. Brown, Teaching by principles: an interactive approach to language pedagogy, 2nd ed. New York: Longman, 2000.

[6] T. Hedge, Teaching and learning in the language classroom. Oxford: Oxford Univeristy Press, 2005.

[7] D. Crystal, English as a global language. Cambridge: Cambridge University Press, 1997.

[8] S. L. McKay, "Teaching English as an international language: The role of culture in Asian context," J. ASIA TEFL, vol. 1, no. 1, pp. 1-22, 2004.

[9] Z. Chen and C. Goh, "Teaching oral english in higher education: Challenges to EFL teachers," Teach. High. Educ., vol. 16, no. 3, pp. 333-345, 2011.

[10] P. Cutrone, "Overcoming Japanese EFL learners' fear of speaking," Univ. Read. Lang. Stud. Work. Pap., vol. Vol. 1, pp. 55-63, 2009.

[11] N. O. Argawati, "IMPROVING STUDENTS' SPEAKING SKILL USING GROUP DISCUSSION ( Experimental study on the First Grade Students of Senior High School )," ELTIN J., vol. 2, pp. 74-81, 2014.

[12] U. Fauzan, "The Use of Improvisations Technique to Improve the Speaking Ability of EFL Students," Din. Ilmu, vol. 14, no. 2, p. 264, 2014.

[13] K. Manurung, "Improving the Speaking Skill Using Reading Contextual Internet-based Instructional Materials in an EFL Class in Indonesia," Procedia - Soc. Behav. Sci., vol. 176, pp. 44-51, 2015.

[14] U. Widiati and B. Y. Cahyono, "The teaching of EFL speaking in the Indonesian context: The state of the art," Bhs. Dan Seni, vol. 34, no. 2, p. 4, 2004.

[15] J. C. Richards, Teaching Listening and Speaking: From Theory to Practice. Cambridge: Cambridge University Press, 2008.

[16] D. Cole, C. Ellis, and B. Mason, Teaching speaking and listening: a toolkit for practitioners. Bristol: Portishead press, 2007.

[17] K. Angkananon and M. Wald, "an Experimental Study of Subtitled Online Video Supporting Thai Students Learning English It Content," Teach. English with Technol., vol. 18, no. 4, pp. 48-70, 2018.

[18] N. Göktürk, "Examining the effectiveness of digital video recordings on oral performance of EFL learners," vol. 16, no. 2, pp. 71-96.

[19] V. Chislett and A. Chapman, "VAK learning styles self-assessment questionnaire," 2005.

[20] A. D. Cohen, "Language learning strategies: How do we get information?," in Learner strategies in language learning, A. Wenden and J. Rubin, Eds. Prentice/Hall International, 1987.

[21] J. Brook, "The Affordances of YouTube for Language Learning and Teaching," Hawaii Pacific Univ. TESOL Work. Pap. Ser., vol. 9, no. 1,2, pp. 37-56, 2011.

[22] A. Burns, Doing action research in English language teaching: A guide for practitioners. New York \& London: Routledge, 2010.

[23] A. Mustikawati, "Effectiveness of using video in teaching speaking for tenth grade students of SMP N 1 Manisrenggo,” Yogyakarta State University, 2013.

[24] A. McNulty and B. Lazarevic, "Best practices in using video technology to promote language acquistion," Teach. English with Technol., vol. 12, no. 3, pp. 49-61, 2012. 